\title{
pFiD188, the Linear Virulence Plasmid of Rhodococcus fascians D188
}

\author{
Isolde Francis, ${ }^{1}$ Annick De Keyser, ${ }^{1,2}$ Philippe De Backer, ${ }^{1}$ Carmen Simón-Mateo, ${ }^{1}$ Jutta Kalkus, ${ }^{1}$ \\ Ine Pertry, ${ }^{1}$ Wilson Ardiles-Diaz, ${ }^{1,2}$ Riet De Rycke,,${ }^{1,2}$ Olivier M. Vandeputte, ${ }^{3}$ Mondher EI Jaziri, ${ }^{3}$ \\ Marcelle Holsters, ${ }^{1,2}$ and Danny Vereecke ${ }^{4}$ \\ ${ }^{1}$ Department of Plant Biotechnology and Bioinformatics and ${ }^{2}$ Department of Plant Systems Biology, VIB, 9052 Gent, \\ Belgium; ${ }^{3}$ Laboratoire de Biotechnologie Végétale, Université Libre de Bruxelles, 6041 Gosselies, Belgium; ${ }^{4}$ Department \\ of Plant Production, University College Ghent, Ghent University, 9000 Gent, Belgium
}

Submitted 25 August 2011. Accepted 21 January 2012.

\begin{abstract}
Rhodococcus fascians is currently the only phytopathogen of which the virulence genes occur on a linear plasmid. To get insight into the origin of this replicon and into the virulence strategy of this broad-spectrum phytopathogen, the sequence of the linear plasmid of strain D188, pFiD188, was determined. Analysis of the 198,917 bp revealed four syntenic regions with linear plasmids of $R$. erythropolis, $R$. jostii, and $R$. opacus, suggesting a common origin of these replicons. Mutational analysis of pFi_086 and pFi_102, similar to cutinases and type IV peptidases, respectively, showed that conserved region $R 2$ was involved in plasmid dispersal and pointed toward a novel function for actinobacterial cutinases in conjugation. Additionally, pFiD188 had three regions that were unique for $R$. fascians. Functional analysis of the stk and $n r p$ loci of regions $\mathrm{U} 2$ and $\mathrm{U} 3$, respectively, indicated that their role in symptom development was limited compared with that of the previously identified fas, att, and hyp virulence loci situated in region U1. Thus, pFiD188 is a typical rhodococcal linear plasmid with a composite structure that encodes core functions involved in plasmid maintenance and accessory functions, some possibly acquired through horizontal gene transfer, implicated in virulence and the interaction with the host.
\end{abstract}

Among the gram-positive Actinomycetales, members of the genus Rhodococcus are renowned for their biotechnological applications and for their ability to degrade a wide variety of organic compounds and xenobiotics (Larkin et al. 2005; van der Geize and Dijkhuizen 2004). Several large, mostly linear, plasmids, harboring the genes encoding characteristic meta-

The sequence data for the linear plasmid pFiD188 of $R$. fascians D188 have been submitted to the GenBank database under accession number JN093097.

Current address for I. Francis: Department of Plant Pathology, University of Florida, Gainesville 32611, U.S.A.

Current address for P. De Backer: Centre de Recherche Public de la Santé, 1A-B, rue Thomas Edison, L-1445 Strassen, Luxemburg.

Current address for C. Simón-Mateo: Centro Nacional de Biotecnología, Consejo Superior de Investigaciones Científicas (CSIC), Campus de Cantoblanco, 28049 Madrid, Spain.

Corresponding author. D. Vereecke; Telephone: +32 92488859; Fax; +32 92424279; E-mail: danny.vereecke@hogent.be

* The $\boldsymbol{e}$-Xtra logo stands for "electronic extra" and indicates that three supplementary tables and one supplementary figure are published online. bolic functions, have been identified in different Rhodococcus spp. (Meinhardt and Klassen 2007). For instance, Rhodococcus jostii RHA1, one of the most effective polychlorinated biphenyl degraders, has three linear plasmids (McLeod et al. 2006), whereas the genes involved in alkane degradation of $R$. erythropolis PR4 (Sekine et al. 2006) and those required for isopropylbenzene and chlorocatechol catabolism of $R$. erythropolis BD2 (Stecker et al. 2003) and R. opacus B4 (GenBank accession number AP011116), respectively, are all located on linear plasmids.

The only plant pathogen within the genus, $R$. fascians, also contains large plasmids that encode special traits, such as heavy metal and antibiotic resistance (Desomer et al. 1988; Lawson et al. 1982). A conjugative circular plasmid (pD188) of $138 \mathrm{~kb}$ had been isolated from the highly virulent strains D188 and NCPPB 1488 and, although cadmium resistance was associated with its presence, virulence was not (Desomer et al. 1988). In their search to isolate the pathogenicity determinants of $R$. fascians D188, Crespi and associates (1992) discovered a conjugative linear plasmid, designated pFiD188, as the carrier of the virulence genes. In other $R$. fascians isolates as well, the occurrence of a linear plasmid was strictly correlated with pathogenicity (Crespi et al. 1992; Stange et al. 1996). In both gram-negative and gram-positive phytopathogens, virulence genes are often located on genomic pathogenicity islands or on circular plasmids (Barash and Manulis-Sasson 2009; Bentley et al. 2008; Bignell et al. 2010; Gal-Mor and Finlay 2006; Vivian et al. 2001) but $R$. fascians is the only phytopathogen known to harbor a linear plasmid that carries the virulence genes (Francis et al. 2007).

$R$. fascians takes a unique position among the hyperplasiainducing plant pathogens because it provokes the formation of differentiated tumors, called leafy galls. The pathology is triggered by the secretion of plant growth regulators, such as cytokinins and auxins, that perturb the hormone balances in the host and turn on a signal transduction cascade in the plant, resulting in the activation of existing meristems and de novo meristem formation (Depuydt et al. 2008; Pertry et al. 2009; Simón-Mateo et al. 2006; Stes et al. 2011; Vandeputte et al. 2005).

By pulsed-field electrophoresis and macro-restriction analysis, the size of pFiD188 was estimated to be between 200 and 210 kb (Crespi et al. 1992; Pisabarro et al. 1998). Since its discovery, three virulence loci have been identified (Crespi et al. 1992). Two of them have been analyzed in detail and proved to be insufficient to render strain D188-5, the plasmid-free derivative of strain D188, pathogenic (Crespi et al. 1992; 1994; Maes 
et al. 2001; Pertry et al. 2010; Temmerman et al. 2000). Therefore, and because these loci represented less than $18 \%$ of the coding potential of the replicon, we set out to uncover the remaining information encoded by $\mathrm{pFiD} 188$. The termini were cloned, the sequence was determined, the structural features were analyzed and compared with those of other linear plasmids, and the genes were annotated. Functional information on three previously uncharacterized loci was obtained through mutation, expression, or biochemical analyses, singly or in combination.

\section{RESULTS AND DISCUSSION}

\section{Sequence characteristics of pFiD188, an invertron-type linear plasmid.}

Linear plasmids of actinomycetes are predominantly of the invertron type, with terminal inverted repeats (TIR) and terminal proteins (TP) covalently linked to their $5^{\prime}$ ends (Meinhardt and Klassen 2007). Pulsed-field gel electrophoresis of bacterial agarose plugs prepared with and without proteolytical treatment and digested with KpnI identified 11.0- and 1.7-kb fragments as the protein-bound termini of pFiD188 (data not shown).

Both fragments were cloned and, although hybridization experiments confirmed their linear plasmid origin, no cross hybridization was observed between the fragments, hinting at a lack of extensive homology between the termini and, hence, of extended TIR (data not shown). Indeed, when the nucleotide sequences of the termini were compared, only one short 7-bp perfect TIR and several other short inverted repeats were identified (Fig. 1A), similar to the termini of the linear replicons of other Rhodococcus spp. but in contrast to the linear plasmids of Streptomyces spp. that have long TIR (Kalkus et al. 1998; Sekine et al. 2006; Stecker et al. 2003).

The sequence of the termini also hinted at a probable linkage of the terminal proteins of pFiD188 to the 5' end via dCMP, as observed for all other linear plasmids from actinomycetes studied so far (Parschat et al. 2007). Calculations based on the energy minimization algorithm mfold (SantaLucia 1998) predicted that, in a single-stranded $3^{\prime}$ overhang, nucleotides might fold back to form a complex secondary structure containing stable hairpins (Fig. 1B). Two central GCTxCGC motifs, conserved in the termini of linear replicons of Rhodococcus and Streptomyces spp. and part of the TP recognition sites (Bao and Cohen 2003; Kalkus et al. 1998), were detected in the telomeric sequences of pFiD188 (Fig. 1A).

To determine the complete sequence of pFiD188, template DNA was obtained by combining several approaches (discussed below) and primer walking resulted in a sequence of 198,917 bp (GenBank accession number JN093097). The calculated average $\mathrm{G}+\mathrm{C}$ content of pFiD188 was $61.8 \%$, which is within the range described for genomic DNA of the genus Rhodococcus (61 to 68\%) (LeChevalier 1986); still, a strong variation was observed in a 100-bp window plot with maxima as high as $77 \%$ and minima as low as $41 \%$ (Supplementary Fig. S1).

\section{pFiD188 shares a common origin} with other rhodococcal linear plasmids.

By combining computer prediction, manual curation, and similarity searches, we identified and annotated 184 open reading frames: 91 gene products had a functional homolog, 56 were conserved hypothetical proteins, and 37 were unique for $R$. fascians (designated "hypothetical proteins") (Supplementary Table S1). The G+C content of the majority of the predicted genes ranged between 60 and $65 \%$ but two continuous regions, consisting of $p F i \_074$ to $p F i \_084$ and $p F i \_111$ to $p F i \_123$, had a $\mathrm{G}+\mathrm{C}$ content that was markedly lower than the pFiD188 average (58 and $58.5 \%$, respectively). Analysis with the Alien Hunter application (Vernikos and Parkhill 2006) predicted that these loci were part of these regions, which, together with three other ones (i.e., $p F i \_011$ to $p F i \_019, p F i \_028$ to $p F i \_036$, $p F i \_072$ to $p F i \_087, p F i \_107$ to $p F i \_125$, and $p F i \_141$ to $\left.p F i \_146\right)$, might have been acquired through horizontal gene transfer (HGT) events.

Most pFiD188-encoded proteins were homologous to proteins of other actinomycetes. This finding is in contrast to the proteins encoded by pVAP, the circular virulence plasmid of the only animal pathogen within the Rhodococcus genus, $R$. equi, that have little or no homology with proteins of any other species (Letek et al. 2010). Even more, pFiD188 was strikingly similar to linear plasmids of several environmental Rhodococ-

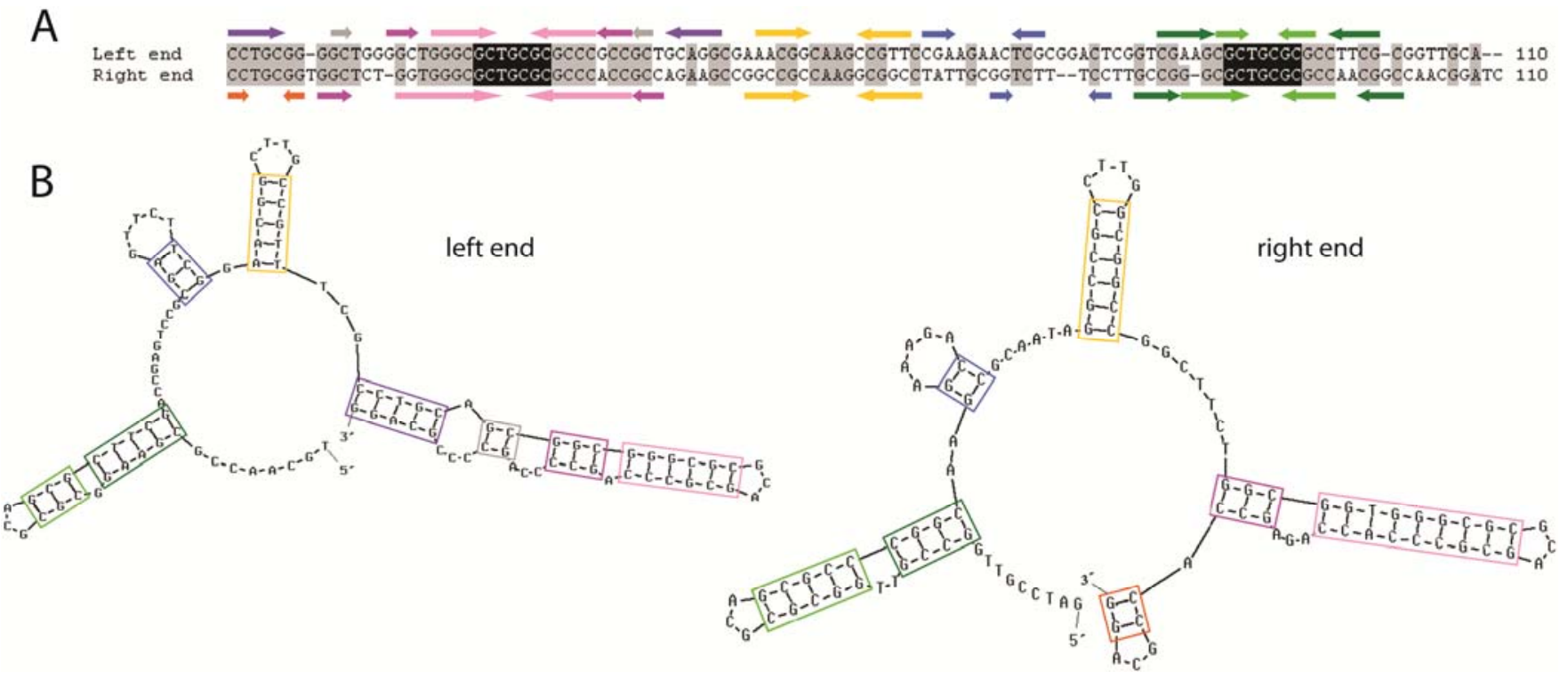

Fig. 1. Structural features of the pFiD188 termini. A, Alignment of the left- and right-end telomeres. Identical bases are boxed in gray; inverted repeats and the GCTxCGC motifs central in the terminal protein recognition site are indicated by converging arrows and in black, respectively. B, Predicted secondary structures formed by the 3' single-stranded DNA sequence of the left- and right-end telomeres (mfold) (SantaLucia 1998). Structures with the lowest energy $(\Delta \mathrm{G}=-30.49 \mathrm{kcal} / \mathrm{mol}$ and $\Delta \mathrm{G}=-37.52 \mathrm{kcal} / \mathrm{mol}$ for the left and right end, respectively) are shown. 
cus spp. Analysis with the Artemis Comparison Tool (Carver et al. 2005) (threshold similarity 90\%) revealed that pFiD188, pBD2, and pREL1 of $R$. erythropolis strains BD2 and PR4 (Sekine et al. 2006; Stecker et al. 2003); pRHL2 of $R$. jostii RHA1 (McLeod et al. 2006); and pROB01 of R. opacus B4 (GenBank accession number AP011116) shared four regions of extensive homology and colinearity (designated R1, R2, R3, and R6 according to Sekine and associates [2006]), implying a common origin for these five linear replicons. Whereas these conserved regions carry functions that are essential for plasmid maintenance, the unique regions of each plasmid (designated $\mathrm{U}$ regions) code for typical features of the particular bacterial strain (Fig. 2).

The conserved region R1 encompasses the left border of pFiD188 and the related linear replicons (Fig. 2). Although some genes had no functional homologs, the R1 region comprised genes putatively involved in natural transformation, plasmid replication, and partitioning. $p F i \_002$ probably codes for a DNA-processing chain A (DprA) protein belonging to the Smf superfamily that is required for natural transformation, a process inherent to almost all bacteria. DprA has been suggested to be involved in the protection of incoming exogenous DNA prior to homology-dependent recombination into the genome (Mortier-Barrière et al. 2007). The gene pair pFi_009 and $\mathrm{pFi} O \mathrm{OHO}$ is conserved in the other rhodococcal linear plasmids and codes for the $5^{\prime}$ terminal and telomere-associated proteins that play a role in telomere patching during replication of linear plasmids (Chen 2007). pFi_O09 is predicted to contain a racA domain that is active in polar chromosome and plasmid segregation and functions in association with a Soj/ParA ATPase (Wu and Errington 2003), which is encoded by $p F i \_013$. Generally, the ATPase activity of ParA is regulated by ParB and the corresponding gene pair is thought to be essential for plasmid partitioning (Surtees and Funnell 2003). However, no putative ParB-coding gene was identified on pFiD188 or on several other linear plasmids from actinobacteria, including pBD2, pREL1, pRHL2, and pROB01. Because the functional significance of this lone parA gene is unclear, plasmid partitioning in actinobacteria might be mediated by another mechanism (Parschat et al. 2007).

The conserved region $\mathrm{R} 3$ encompasses a region with extensive homology to the tight adherence (tad) locus ( $p F i \_020$ to pFi_O26) (Fig. 2), initially identified as an essential virulence factor in Actinobacillus actinomycetenscomitans, the causative agent of localized juvenile periodontitis but present in many archaeal and bacterial species (Tomich et al. 2007). The Tad proteins form a macromolecular transport system required for the assembly of adhesive pili necessary for biofilm formation, colonization, and pathogenesis (Tomich et al. 2007). Biofilm formation is essential in natural bacterial populations to ensure their survival under harsh conditions and it is also an important mechanism for the colonization of target tissues by pathogens, which is the first phase of pathogenicity (Danhorn and Fuqua 2007). R. fascians forms pellicles on the surface of liquids (Fig. 3A) and extensively colonizes leaf surfaces (Cornelis et al. 2001) (Fig. 3B). Thus, although the conservation of region R3 in rhodococcal linear plasmids might point to a general role in bacterial ecology, it cannot be ruled out that this region might also contribute to the $R$. fascians virulence by promoting attachment to the plant.

The third conserved region, R6, encodes mainly conserved hypothetical proteins (Fig. 2); thus, its function in the plasmid biology is unknown. The regions R4 (the most elaborate homology region between pBD2, pREL1, and pROB01) and R5 are not conserved on pFiD188 or pRHL2; R5 is not present on pROB01, either (Fig. 2). The gene products encoded by these two regions are involved in lipoprotein processing and heavy metal and arsenate resistance, respectively (Sekine et al. 2006). In $R$. fascians D188, heavy metal resistance (cadmium) is carried on a separate replicon, the circular plasmid pD188 (Desomer et al. 1988).

\section{The conserved region $R 2$ is involved in conjugative plasmid transfer.}

The conserved R2 region contains mostly hypothetical proteins with predicted transmembrane domains (TMD) (Fig. 2). However, $p F i \_086$, the middle gene of a putative three-gene operon, is homologous to cutinases, a distinct class of extracellular plant cell-wall-degrading enzymes that have been identified and studied mainly in fungi. Cutinases are serine esterases that function in the hydrolytic degradation of the cuticula by targeting mostly primary alcohol esters of the cutine polymer (Carvalho et al. 1999; Schäfer 1993). Despite extensive screening, cutinase activity does not seem to be widespread among bacteria (West et al. 2009), and analysis of bacterial genomic sequences reveals that cutinase homologs seem to be largely restricted to the gram-positive Corynebacterinae (pfam PF01083). Hardly any information is available on the role of cutinases in these organisms but hypothetical functions have been postulated in virulence, saprophytic growth, in vivo sur-

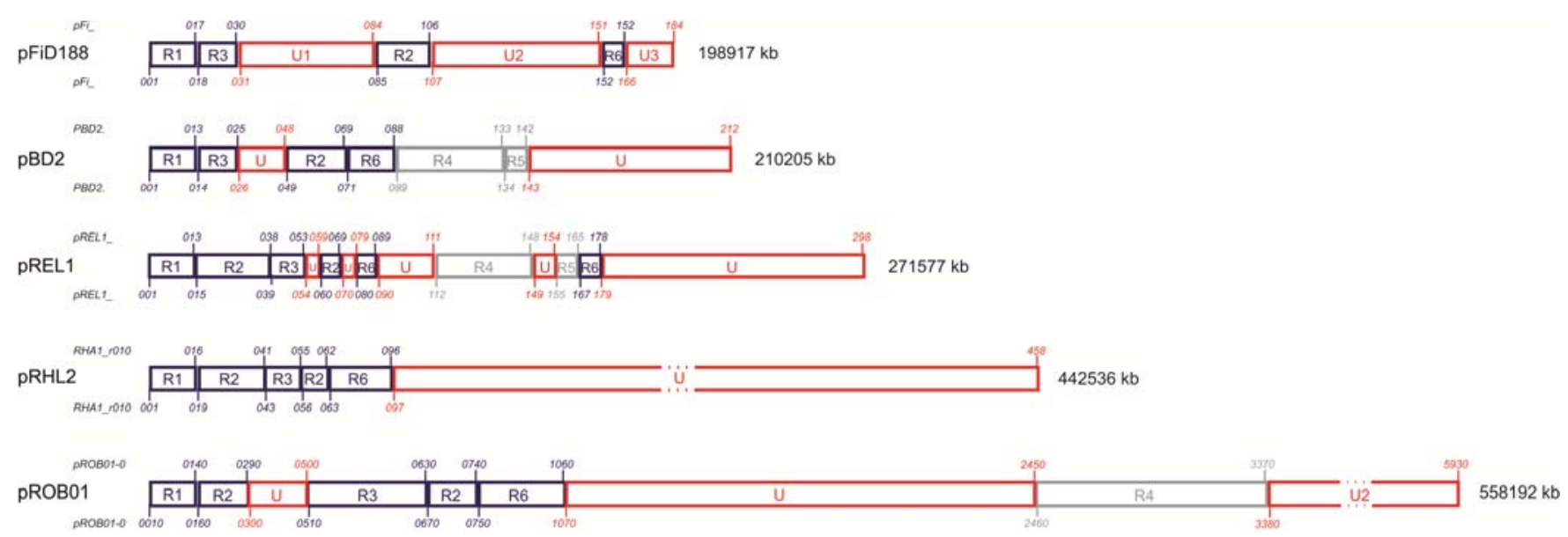

Fig. 2. Schematic representation of the composite structure of rhodococcal linear plasmids, based on protein similarity plots generated by the Artemis Comparison Tool (threshold similarity 90\%). pFiD188 (Rhodococcus fascians), pBD2 (R. erythropolis BD2), pREL1 (R. erythropolis PR4), pRHL2 (R. jostii RHA1), and pROB01 (R. opacus B4). The open reading frame range of conserved $(\mathrm{R})$ and unique $(\mathrm{U})$ regions and the size of the linear plasmids are indicated. 
vival, bacterial lipid metabolism, or enzymatic manipulation of the bacterial cell envelope during growth, cell division, or autolysis (West et al. 2009). Interestingly, analysis with the Alien Hunter application predicted that the cutinase operon on pFiD188 would be acquired through HGT.

Because endophytic populations are established by $R$. fascians (Cornelis et al. 2001), we postulated that the pFi_086encoded protein would be required to breach through the cuticula and the epidermal barrier of its host. Indeed, the plasmid-free strain D188-5 only forms discrete endophytic populations (Cornelis et al. 2001), suggesting that the linear plasmid carries functions that greatly enhance penetration of and dissemination into the plant tissues. The role of the cutinase gene in virulence was evaluated by generating a cutinase deletion mutant, D188- $\Delta c u t i$, by means of exchange recombination. Unexpectedly, infection of unwounded excised tobacco (Nicotiana tabacum) lraves with the D188- $\Delta$ cuti mutant resulted in leafy galls that were similar to those induced

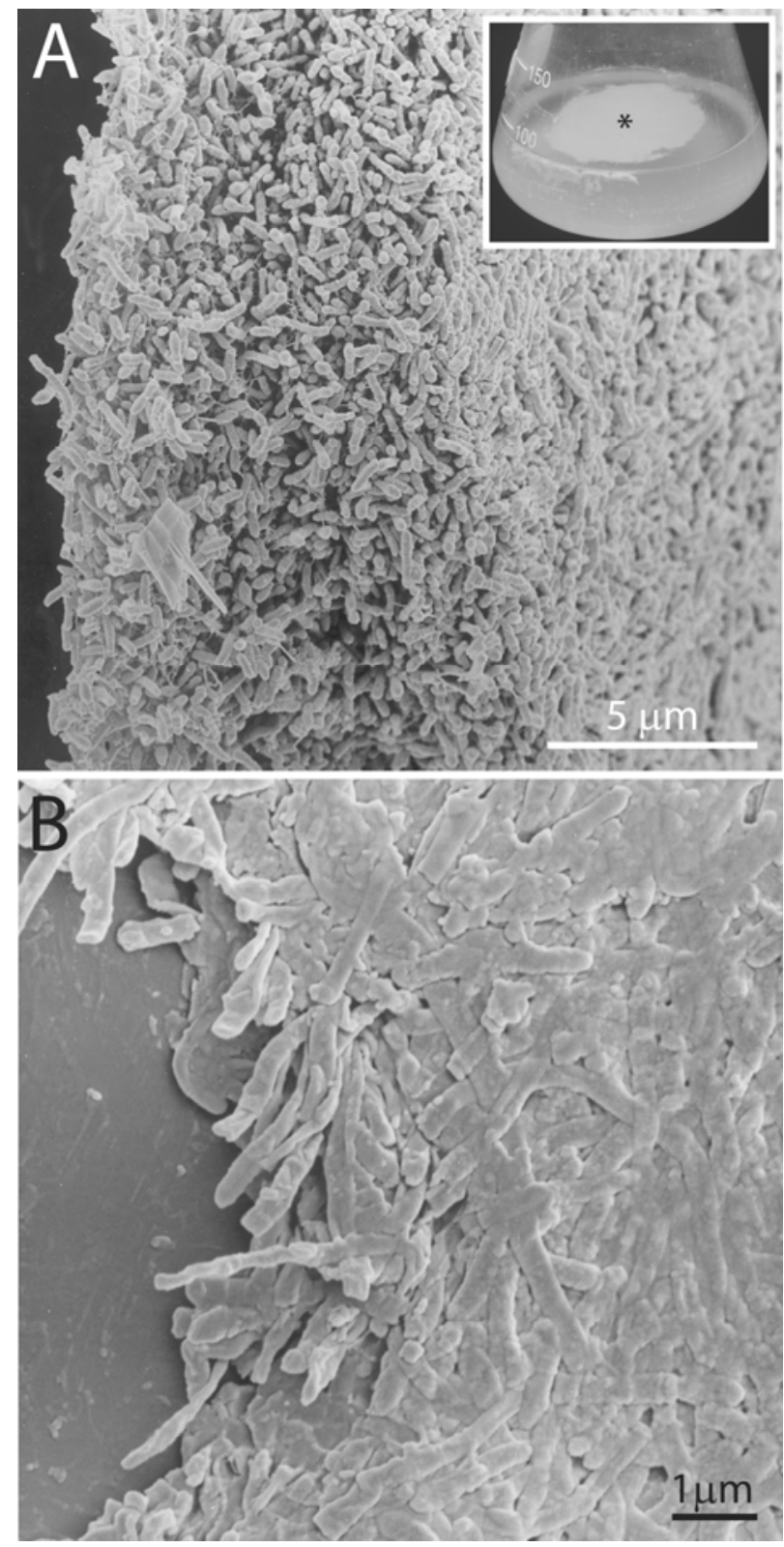

Fig. 3. Biofilm formation by Rhodococcus fascians D188 populations. A, Detail of a pellicle formed on the liquid-air interphase of a bacterial culture. The inset shows a macroscopic view of the pellicle (indicated by *). B, Epiphytic biofilm on a tobacco leaf. by the wild-type strain (Fig. 4A and B), not supporting the hypothesis that the function of the cutinase of $R$. fascians is analogous to that of fungi.

Interestingly, five of the genes in region $\mathrm{R} 2$ encode proteins that might possibly be involved in conjugation. $p F i$ O92 putatively codes for an ATP/GTP-binding protein of the VirB4 family, pFi_093 is a polytopic integral membrane protein, and pFi_098 is similar to DNA translocases of the FtsK/SpoIIIE family. Together, these proteins might constitute a functional DNA translocase complex (Barre 2007). pFi_094 is homologous to genes encoding lytic transglycosylases and could play a role in the local opening of the peptidoglycan layer (Grohmann et al. 2003). pFi_102 putatively encodes a prepilin-type IV peptidase, one of the players in the formation of type IV pili known to be involved in the interbacterial contact required for conjugation in gram-positive bacteria (Grohmann et al. 2003). Indeed, R. fascians forms cellular protrusions that resemble type IV pili during conjugation (Fig. 4C). These data suggested that the R2 region of pFiD188 might code for a membrane-associated conjugation complex. To validate this hypothesis, we tested the transfer frequency of the mutant linear plasmids from D188- $\Delta$ cuti and from a $p F i \_102$ insertion mutant into the plasmid-free acceptor strain D188-5. As a control, D188- $\triangle a t t R$ (Maes et al. 2001) was chosen because it is resistant to kanamycin $(\mathrm{Km})$ and has a single interrupted gene, like the test strains D188- $\Delta c u t i$ and D188-pFi_102. The pFi transfer frequency from D188- $\Delta c u t i$ and D188- $p F i \_102$ was 60 - to 100 -fold lower than that of D188- $\Delta a t t R$, indicating that both gene functions are important for efficient conjugation (Fig. 4D). Introduction of complementation constructs containing $\mathrm{pFi} 086$ into D188- $\Delta c u t i$ largely restored the transfer frequency, thus supporting this finding for the cutinase gene (Fig. 4D). The occurrence of cutinase genes restricted to members of the Corynebacterinae strongly implies that cutinases in these organisms function primarily in cell wall metabolism and facilitate conjugation, most probably by local loosening of the mycolic acid cell wall that borders the peptidoglycan layer.

\section{The unique region $\mathrm{U} 1$ is the main pathogenicity region.}

Of the three unique regions of pFiD188, U1 is the largest and contains the previously identified virulence loci fas, att, and hyp (Crespi et al. 1992; Maes et al. 2001; Rajaonson et al. 2011) (Fig. 2). Interestingly, the fas operon ( $p F i \_077$ to $\left.p F i \_082\right)$ that is the central virulence locus and encodes the enzymatic machinery for cytokinin production (Pertry et al. $2009,2010)$ has a low $\mathrm{G}+\mathrm{C}$ content $(58.8 \%)$ and is located in one of the regions identified with the Alien Hunter application as possibly being acquired through HGT. In this region, four additional genes ( $p F i \_075, p F i \_076, p F i \_083$, and pFi_084) colocalize with the fas locus; therefore, their gene products might be implicated in cytokinin production or virulence. pFi_075 and $p F i \_076$ encode $S$-adenosylmethioninedependent methyltransferases and they are conserved in the fas locus of Streptomyces turgidiscabies, another plant-pathogenic actinomycete capable of inducing leafy galls, as part of a pathogenicity island thought to be acquired through HGT (Joshi and Loria 2007). Interestingly, mutants in pFi_O75 and pFi_076 are nonpathogenic (Pertry 2009).

In addition to these known virulence loci, region $\mathrm{U} 1$ also contains a biosynthetic gene cluster ( $p F i \_055$ to $\left.p F i \_062\right)$ that putatively produces a $\gamma$-butyrolacton-type autoregulator typically involved in cell-to-cell signaling and control of secondary metabolite production (Kato et al. 2007). Possibly, this autoregulator is involved in the regulation of cytokinin (Pertry 2009) or auxin biosynthesis (Vandeputte et al. 2005) in R. fascians. 
Finally, the region U1 contains a putative toxin-antitoxin system (pFi_041 and pFi_042), originally identified as a mechanism to ensure plasmid inheritance or stability (Van Melderen and De Bast 2009). However, pFiD188 is not essential for growth, because a plasmid-free derivative could be isolated easily (Desomer et al. 1988). Moreover, this system is not conserved in the related rhodococcal linear plasmids, all arguing against such a function in $R$. fascians. Nevertheless, pFiD188 has proven to be extremely stable both under culture conditions and in plant tissues (D. Vereecke, personal communication). In the latter, the presence of pFiD188 in the bacteria is essential for the continuous production of plant growth regulators that are instrumental for niche maintenance (Vereecke et al. 2000). Therefore, it cannot be ruled out that pFi_041 and pFi_042 are involved in plasmid stability during the epi- and endophytic phases of the $R$. fascians life cycle. However, in several bacterial species, chromosomal homologs of toxin-antitoxin genes have been identified that cleave mRNA or phosphorylate proteins in response to nutritional stress, thereby inducing a transient state of cell cycle arrest that allows the bacteria to persist under starvation or other adverse conditions (Hayes and Low 2009). In Mycobacterium tuberculosis, such mechanisms have been implicated in the apparent metabolic dormancy of cells that mediate persistent infections (Zhu et al. 2006). Because $R$. fascians and $M$. tuberculosis share persistence strategies (Vereecke et al. 2002), it is tempting to assume that pFi_041 and pFi_042 encompass a mechanism involved in successful survival in plant tissues.

Altogether, the genes present in the U1 region apparently seem to be either genuine virulence factors or involved in pathogenicity regulation. Therefore, this region is considered to be the main pathogenicity island on pFiD188.

\section{The putative nonribosomal peptide synthetase located} in the unique region $\mathrm{U} 2$ is not essential for virulence.

Most genes within the unique U2 region have no significant homologs and their role in the $R$. fascians biology remains to be determined (Fig. 2). Nevertheless, the largest gene cluster of the unique $\mathrm{U} 2$ region consists of 13 genes ( $p F i \_111$ to $\left.p F i \_123\right)$ with the same transcriptional orientation; their low

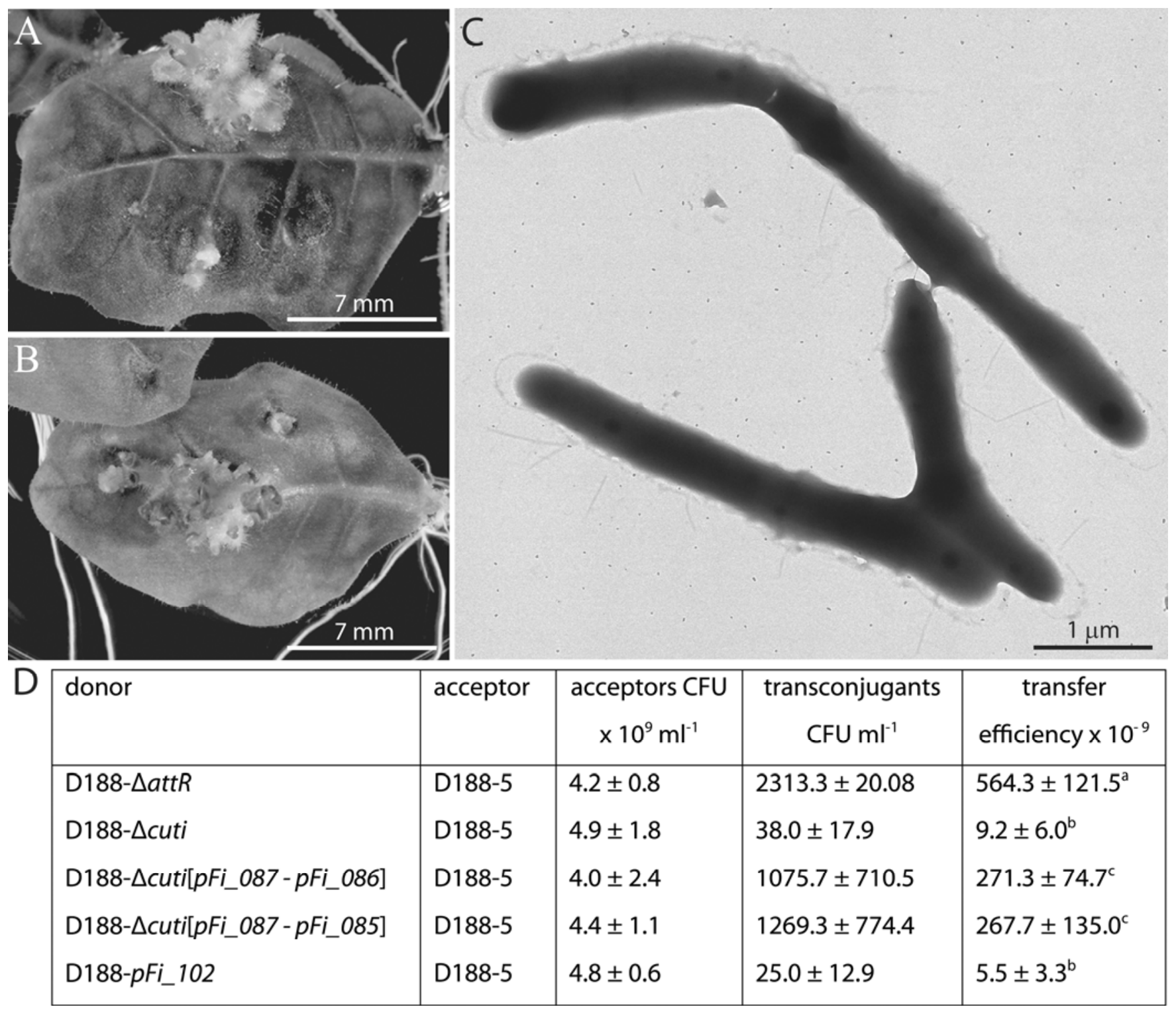

Fig. 4. Conjugation-related aspects of Rhodococcus fascians. A, Leafy gall formation of strain D188 on excised tobacco leaves. B, Leafy gall formation of mutant strain D188- $\Delta$ cuti on excised tobacco leaves. C, Pili-like structures connecting $R$. fascians cells during conjugation. D, Efficiency of transfer of pFiD188 from D188- $\Delta c u t i$, complemented D188- $\Delta c u t i$, and D188-pFi_102 compared with that of D188- $\Delta a t t R$ as a control. Different letters indicate statistically significant differences in the conjugation frequency according to Student's $t$ tests $(P<0.05)$. 
$\mathrm{G}+\mathrm{C}$ content $(58.5 \%)$ and Alien Hunter analysis implies that they might have been acquired via HGT. Based on homology to nonribosomal peptide synthetases (NRPS), this cluster was designated the nrp locus. NRPS are large multienzyme complexes organized in modular subunits that can each incorporate a single substrate and act together in a template-based mode to achieve a specific N-to-C-terminal stepwise assembly of the peptide chain (Finking and Marahiel 2004). The semi-autonomous modules contain highly conserved core motifs involved in recognition, activation, thiolation, and, optionally, modification of the substrate (Konz and Marahiel 1999) (Fig. 5A).

In Nrp5, Nrp7, Nrp8, and Nrp9, distinct functional domains could be identified but a modular arrangement was absent in all except Nrp5 (Fig. 5B). Therefore, it is not possible to predict the chemical structure of the produced peptide based on their deduced amino acid sequence. The other nrp genes might participate in the modification of the NRPS peptide.

Because coexpression with virulence determinants often indicates involvement in pathogenicity, we first monitored the expression of $n r p 5$ via a $\beta$-glucuronidase $(g u s)$ reporter strain grown under conditions that activate the $R$. fascians virulence genes (Materials and Methods). However, a comparable and constitutive expression level was measured for all growth conditions tested (data not shown). To examine a possible role in virulence, we generated a deletion mutant that lacks the adenylation domain of module 3 of Nrp5, D188- $\Delta n r p 5$, via double homologous recombination (Fig. 5B). Different infection procedures with D188- $\Delta n r p 5$ induced symptoms on tobacco that were indistinguishable from those induced by strain D188 (Fig. 5C). These observations imply that the nrp locus does not encode an essential virulence factor but alternative functions in the $R$. fascians pathology might be related to host range, ecological fitness, or bacterial competitiveness.
The stk operon of the unique $\mathrm{U} 3$ region is putatively involved in phosphate-dependent cell wall modification but is not implicated in symptom induction.

Whereas one end of the five related linear rhodococcal replicons is conserved, the other end is unique for each plasmid (Fig. 2). In pFiD188, this region mainly encodes (conserved) hypothetical proteins but, interestingly, it also harbors the stk operon ( $p F i \_176$ to $p F i \_180$ ), which is homologous to a conserved gene cluster essential for proper cell division found in all sequenced actinomycetes to date (Fig. 6A). In these clusters, regulatory proteins active in serine/threonine phosphorylation/dephosphorylation events occur together with proteins implicated in cell wall biosynthesis and morphogenesis. The colinearity and the absence of a comparable cluster in the genomes of other prokaryotes suggest that this locus is specific for a cell divisionassociated regulatory pathway, corresponding to the high $\mathrm{G}+\mathrm{C}$ branch of the gram-positive bacteria (Molle and Kremer 2010). Thus, the occurrence of the stk operon on pFiD188, which is dispensable for bacterial growth and survival, implies that it has acquired a different function in $R$. fascians.

The first gene of the $s t k$ operon, stkl ( $\left.p F i \_176\right)$, encodes a serine/threonine kinase (Jones and Dyson 2006). The hydropathy profile of the Stk1 protein predicts the presence of four $\mathrm{N}$ terminal TMD, creating a putative extracellular $\mathrm{N}$-terminal sensor module. Typically, the extracellular modules of the sensor kinases of the conserved actinobacterial clusters contain PASTA domains involved in $\beta$-lactam binding (Yeats et al. 2002) but such motifs are absent from the putative sensor domain of Stk1, suggesting that it probably responds to a different type of ligand.

The gene product of $s t k 2$ ( $\left.p F i \_177\right)$ has two TMD and is homologous to members of the protein phosphatase $\mathrm{Mg}^{2+}$ or $\mathrm{Mn}^{2+}$-dependent family that catalyzes the dephosphorylation of

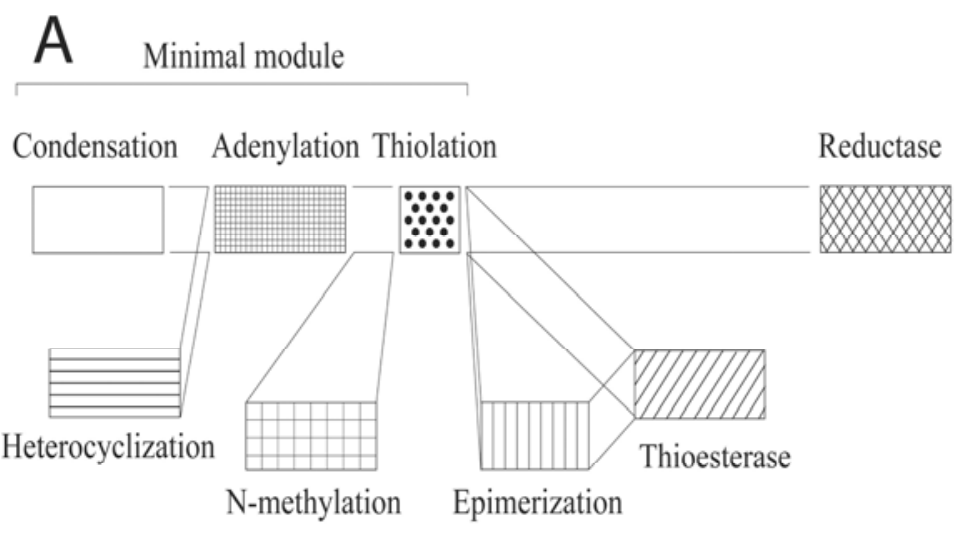

B

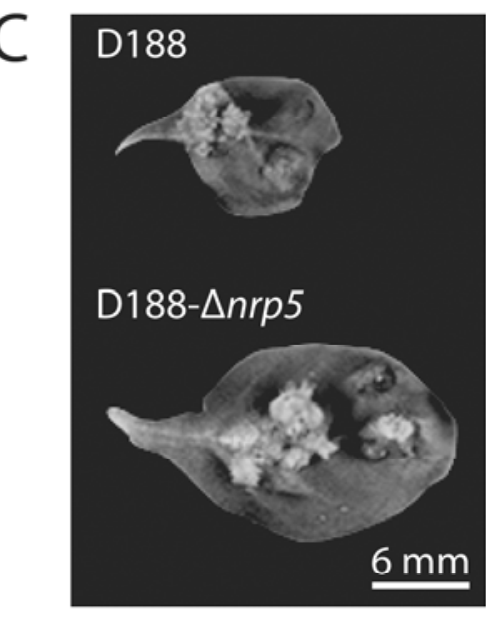

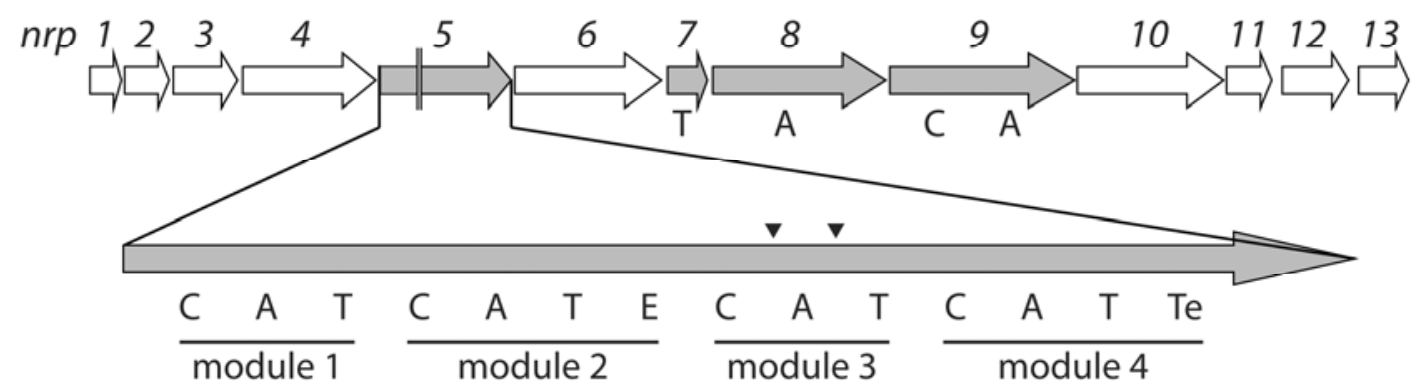

Fig. 5. The $n r p$ locus of pFiD188. A, Structural organization of the domains in a typical NRPS module. B, Schematic representation of the nrp locus. The condensation (C), adenylation (A), thiolation (T), epimerase (E), and thioesterase (Te) domains of Nrp5, Nrp7, Nrp7, Nrp8, and Nrp9 are indicated. The white $n r p$ genes do not contain any domains. The deleted region in D188- $\Delta$ nrp5 is marked by two arrowheads. C, Symptoms induced by D188 and D188$\Delta$ nrp5 on excised tobacco leaves. 
phosphoserine- and phosphothreonine-containing proteins (Zhang and Shi 2004). The stk3-encoded protein (pFi_178) has one TMD and a C-terminal forkhead-associated domain, known to bind phosphothreonine-containing peptides and mediating phosphorylation-dependent protein-protein interactions (Liang and Van Doren 2008). Gene stk4 ( $\left.p F i \_179\right)$ encodes a protein with two functionally distinct domains. The N-terminal part of Stk 4 is characterized by 12 TMD and shows similarity to RodA/FtsW proteins that belong to the "shape, elongation, division, and sporulation" family of integral membrane proteins conserved in bacteria with a peptidoglycan cell wall (Letek et al. 2008). The C-terminus of Stk4 is homologous to the transpeptidase domain of class B penicillin-binding proteins (PBP). These high-molecular weight PBP function in the assembly of the cell wall by cross-linking peptidoglycan strands via their peptide side chains and are responsible for septum formation during cell division and maintenance of the cell shape during elongation. Interestingly, in other prokaryotes, RodA/FtsW and Class B PBP operate as a functional couple in which RodA/FtsW is proposed to recruit the PBP to their appropriate location in the cell membrane (Letek et al. 2008; Sauvage et al. 2008). Most PBP are anchored to the membrane via a single TMD. The composite nature of Stk4 strengthens the functional coupling between the PBP and the RodA/FtsW domain and might ensure the firm anchoring of the PBP to the membrane at the location dictated by RodA/FtsW. The last gene of the operon, stk5 ( $p F i \_180$ ), encodes a soluble hypothetical protein.

Taken together, we postulate that cross-interaction between Stk1 and Stk2 could translate environmental signals into cellular responses through changes in the phosphorylation state of Stk3. Phosphorylated Stk3 could then modulate the PBP activity of Stk4 and, hence, the peptidoglycan biosynthesis or modulation, leading to morphological cell changes that might be important in the interaction with or survival in the plant host. This hypothesis was partially substantiated by biochemical analysis of Stk1 and Stk2. To prevent purification difficulties, an N-terminal maltosebinding protein (MBP)-tagged version of the Stk1 protein without the TMD was produced in Escherichia coli (MBP-Stk $1_{\text {sol }}$ ). In contrast to other stk-like genes (Jin and Pancholi 2006), heterologous expression of $s t k 1$ did not affect the cell morphology of E. coli (data not shown). MBP-Stk $1_{\text {sol }}$ exhibited autokinase activity in the presence of $\mathrm{Mn}^{2+}$ and $\mathrm{Mg}^{2+}$ as cofactors, with a preference for $\mathrm{Mn}^{2+}$; no autophosphorylation was detected in the presence of $\mathrm{Ca}^{2+}$ ions. A truncated Stk1 (Stk1 $\left.1_{\text {trunc }}\right)$, lacking the

Fig. 6. The $s t k$ operon of pFiD188. A, Structure of $s t k$-like loci in actinobacteria. Genes coding for serine/threonine protein kinases (red), penicillin-binding proteins (green), RodA/FtsW proteins of the "shape, elongation, division, and sporulation" family (yellow), protein phosphatases (blue), forkhead-associated domain-containing proteins (purple), and hypothetical proteins (gray) are shown. B, Stk1, a functional protein kinase. Sodium dodecyl sulfate polyacrylamide gel electrophoresis (SDS-PAGE) of the purified maltose-binding protein (MBP)-Stk $1_{\text {sol }}$ and MBP-Stk $1_{\text {trunc }}$ fusion proteins from Escherichia coli (left). In vitro autophosphorylation of MBP-Stk $1_{\text {sol }}$ and MBP-Stk $1_{\text {trunc }}$ in the presence of different divalent cations at various concentrations (right). $\mathrm{M}$, molecular weight marker. C, Stk2, a functional phosphatase. Hydrolysis of $p$-nitrophenyl phosphate by purified MBP-Stk $2_{\text {sol }}$ in the presence of different concentrations of $\mathrm{MnCl}_{2}$ : $\bigcirc, 0 \mathrm{mM} \mathrm{MnCl} 2 ; \square, 0.1 \mathrm{mM} \mathrm{MnCl}{ }_{2} ; \triangle, 0.5 \mathrm{mM} \mathrm{MnCl}_{2} ; \diamond, 1 \mathrm{mM}$ $\mathrm{MnCl}_{2} ; \bigcirc 2 \mathrm{mM} \mathrm{MnCl}_{2} ; \mathbf{\square}, 10 \mathrm{mM} \mathrm{MnCl}$. D, Cross-reaction between the Stk proteins. SDS-PAGE of the purified fusion proteins (left) and autoradiogram of the protein gel (right). Proteins that are combined in the enzymatic reactions are indicated above each lane. Dephosphorylation of autophosphorylated MBP-Stk $1_{\text {sol }}$ by MBP-Stk $2_{\text {sol }}$ (lanes 1 and 2); transphosphorylation of MBP-Stk3 by MBP-Stk $1_{\text {sol }}$ (lane 3 ), but not by MBPStk $1_{\text {trunc }}$ (lane 5); MBP-Stk4 $4_{\text {sol }}$ is not a substrate for MBP-Stk $1_{\text {sol }}$ (lane 4). MBP-Stk $1_{\text {sol }}$ (arrow); MBP-Stk3 (asterisk); MBP-Stk4 $4_{\text {sol }}$ (hash). E, Leafy gall formation on excised tobacco leaves.
ATP-binding subdomain, yielded a nonfunctional kinase (Fig. 6B).

The phosphatase activity of Stk2 was assessed by heterologous production of an $\mathrm{N}$-terminal MBP-tagged version of the protein without the TMD in E. coli (MBP-Stk $\left.2_{\text {sol }}\right)$. MBP$\mathrm{Stk} 2_{\text {sol }}$ hydrolyzed the model substrate $p$-nitrophenyl phosphate (pNPP) into $p$-nitrophenol in the presence of $\mathrm{Mn}^{2+}$ only (Fig. 6C). To test whether Stk1 and Stk2 cross-reacted, we incubated purified MBP-Stk $1_{\text {sol }}$ with $\left[\gamma-{ }^{33} \mathrm{P}\right] \mathrm{ATP}$ under optimal conditions for autokinase activity. The subsequent incubation of radiolabeled MBP-Stk $1_{\text {sol }}$ with purified $S t k 2_{\text {sol }}$ led to the

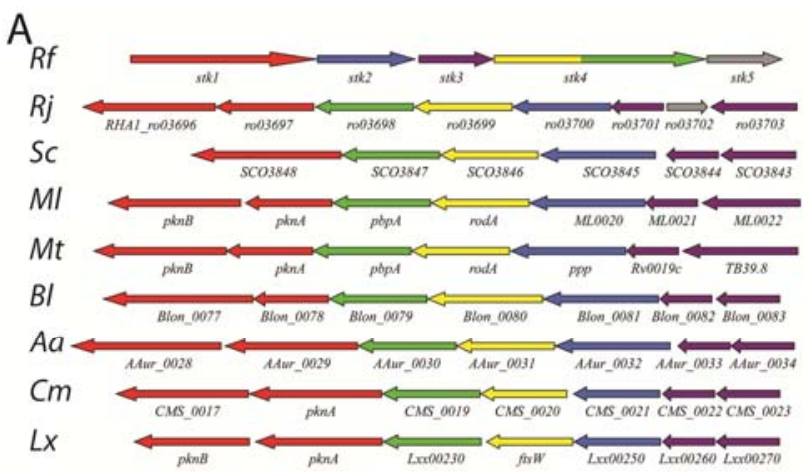

B

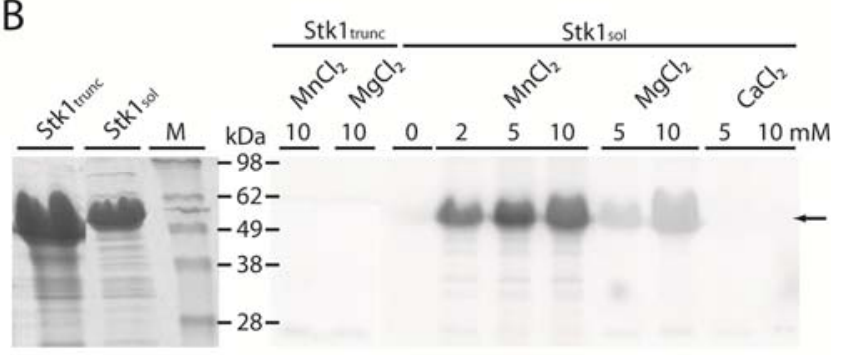

C

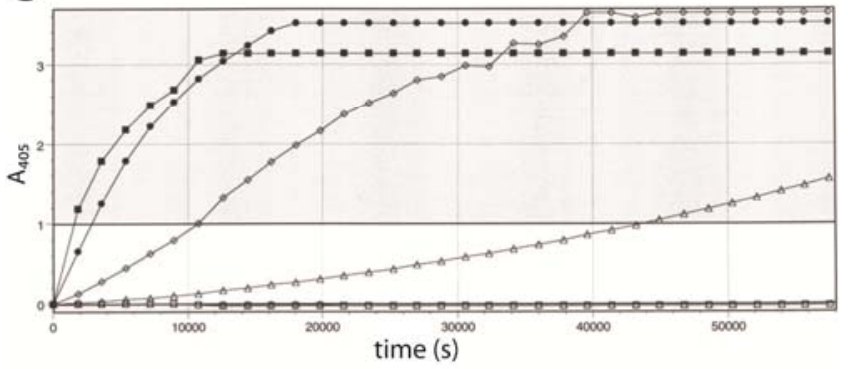

D

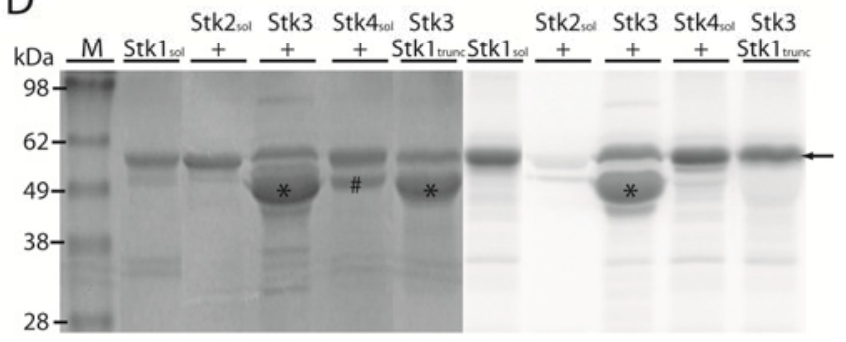

$\mathrm{E}$

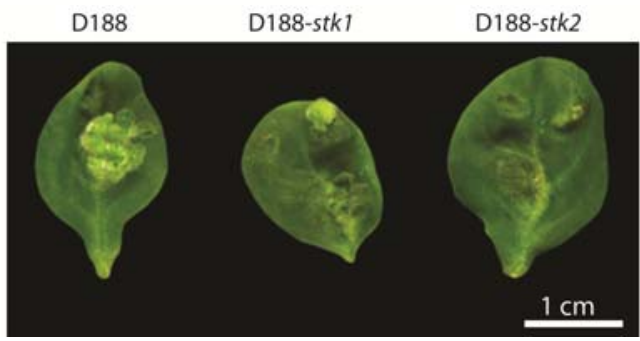


almost complete disappearance of the signal corresponding to the autophosphorylated kinase (Fig. 6D), indicating that the kinase activity of Stk1 is controlled through dephosphorylation by its cognate protein phosphatase Stk2. Finally, to check the intermolecular phosphorylation capacity of Stk $1_{\text {sol }}$, N-terminal MPB-tagged versions of Stk3 and of the PBP part of Stk4 were produced in E. coli. Incubation of autophosphorylated MBPStk $1_{\text {sol }}$ with MBP-Stk3 and MBP-Stk $4_{\text {sol }}$ revealed that Stk3 but not the C-terminal part of Stk4 was a substrate for Stk1 (Fig. $6 \mathrm{D})$. No phosphorylation occurred when $S t k 1_{\text {sol }}$ was replaced by $\mathrm{Stk} 1_{\text {trunc }}$ (Fig. 6D).

Assessment of the expression of stk1 and stk4-gus reporter strains revealed that both genes were constitutively expressed under all conditions tested (data not shown) and the symptoms induced by an stkl and stk 4 mutant on tobacco were comparable with those provoked by the wild-type strain D188 (Fig. $6 \mathrm{E})$. Nevertheless, the presence of the locus in a unique region of the virulence plasmid of $R$. fascians hints at a specialized, still-unknown function for the stk locus in the interaction with its host. Possibly, the stk operon might be involved in the reported modification or complete loss of the bacterial cell wall of the endophytic population (Cornelis et al. 2001; Lacey 1961). Alternatively, because $R$. fascians is a nonmotile bacterium, the stk locus could function in polar peptidoglycan production, allowing hyphal and, possibly, directional growth toward a host. Indeed, apical growth in the actinomycete genus Streptomyces occurs in a phosphorylation-dependent way (Flärdh 2010) and elongated $R$. fascians cells have been observed on leaves (Cornelis et al. 2001).

\section{Concluding remarks.}

In contrast to the virulence plasmid of the animal pathogen $R$. equi, the structural organization of pFiD188 of $R$. fascians is largely similar to that found in the linear plasmids pBD2, pREL1, pRHL2, and pROB01 of $R$. erythropolis strains BD2 and PR4, $R$. jostii RHA1, and $R$. opacus $\mathrm{B} 4$, respectively, strongly implying a common origin. Just like the related environmental rhodococcal linear plasmids, pFiD188 has a composite structure with conserved regions involved in plasmid maintenance and unique regions implicated in the pathogenic and plant-associated life style of $R$. fascians. Interestingly, the gene products of these unique regions of pFiD188 are often highly similar to proteins of other nonpathogenic actinomycetes. Thus, in $R$. fascians, the evolution toward interaction with a plant host and disease elicitation might have occurred through a mechanism that reoriented the function of core actinobacterial traits, combined with acquisition of genuine virulence factors and genes involved in adaptation to the plant niche, possibly via HGT. These different classes of gene origin are illustrated by the $s t k$, fas, and $n r p$ loci. However, many genes in the unique regions of pFiD188 are found solely in $R$. fascians or encode conserved hypothetical proteins. Therefore, the availability of the sequence of pFiD188 combined with ongoing extensive transposon-mediated mutagenesis (O. Vandeputte, personal communication) offers new opportunities and challenges to unravel the pathogenicity strategies of $R$. fascians.

\section{MATERIALS AND METHODS}

\section{Bacterial strains, plasmids, and growth conditions.}

An overview of the $R$. fascians strains and plasmids used is given in Supplementary Table S2. R. fascians strains were grown at $28^{\circ} \mathrm{C}$ in yeast extract broth (YEB) (Sambrook and Russell 2001) supplemented, when required, with chloramphenicol $(\mathrm{Cm})$ at $25 \mu \mathrm{g} \mathrm{ml}^{-1}, \mathrm{Km}$ at $50 \mu \mathrm{g} \mathrm{ml} \mathrm{m}^{-1}$, phleomycin (Phleo) at $1 \mu \mathrm{g} \mathrm{ml}^{-1}$, or streptomycin (Sm) at $100 \mu \mathrm{g} \mathrm{ml}^{-1}$. The E. coli DH5 $\alpha$ (Hanahan 1983) was used for cloning purposes and to propagate a D188 genomic cosmid library (Desomer et al. 1991). Cells were grown at $37^{\circ} \mathrm{C}$ in Luria-Bertani medium (Sambrook and Russell 2001) supplemented, when required, with carbenicillin $(\mathrm{Cb})$ at $100 \mu \mathrm{g} \mathrm{ml}^{-1}$ or $\mathrm{Km}$ at $50 \mu \mathrm{g} \mathrm{ml}^{-1}$.

\section{Identification of the plasmid ends.}

$R$. fascians cells were grown in $5 \mathrm{ml}$ of YEB for 2 days at $28^{\circ} \mathrm{C}$, diluted 50 -fold in $100 \mathrm{ml}$ of $\mathrm{YEB}$, and allowed to grow overnight. Culture aliquots of $6 \mathrm{ml}$ were centrifuged, embedded in LMP agarose, and lysed using lysozyme, $N$-lauroylsarcosine, and proteinase K as described (Kalkus et al. 1998). Proteinase K was omitted for the preparation of nonproteolytically treated plasmid. The plugs were washed with TE buffer (10 $\mathrm{mM}$ Tris and $1 \mathrm{mM}$ EDTA, $\mathrm{pH} \mathrm{8.0)}$ in which they were stored at $4^{\circ} \mathrm{C}$ until further processing.

For the isolation of the linear plasmid ends, restriction with KpnI was carried out in situ in the proteolytically and nonproteolytically treated agarose plugs. The restriction digest was loaded on $1 \%$ agarose gels (Pulsed Field Certified Agarose; Bio-Rad, Hercules, CA, U.S.A.) in $0.5 \times$ Tris-borate-EDTA buffer and resolved by contour-clamped homogeneous electric field electrophoresis at $6 \mathrm{~V} \mathrm{~cm}^{-1}$ for $18 \mathrm{~h}$ at $14^{\circ} \mathrm{C}$ with a field angle of 120 degrees and a ramped pulse time from 1 to $30 \mathrm{~s}$ (CHEF MAPPER; Bio-Rad). The fragments showing a modified electrophoretic mobility were cloned into pBluescript.

\section{Generation of template DNA \\ for sequencing and gap closure.}

For sequencing pFiD188, a first source of template DNA was a genomic cosmid library of $R$. fascians D188 (Desomer et al. 1991). Additional DNA fragments were generated through cloning of restriction fragments that had been identified as overlapping with cosmid borders via DNA gel blot hybridization analysis. By using a genome-walking method optimized for GC-rich template DNA (Gröning et al. 2010) and vectorette polymerase chain reaction (PCR) (Arnold and Hodgson 1991), sequences of unknown regions adjacent to known DNA regions were amplified and cloned into pCRBlunt for subsequent sequencing.

Intriguingly, the DNA fragment that bridged both final contigs could not be cloned in E. coli because it was highly unstable; eventually, it was obtained by inverse PCR and direct sequencing (Ochman et al 1988). Therefore, genomic DNA of strain D188 was treated with SphI (left contig) or SacI (right contig). After heat inactivation and self-ligation, the DNA was relinearized with KpnI (left contig) or EcoRV (right contig). With two outward sequence-specific primers for both contigs, the sequence of the unknown fragment was determined.

\section{Sequencing and annotation.}

The EZ-Tn5 <TET-1> transposon insertion kit (Epicentre Biotechnologies, Madison, WI, U.S.A.) was used to randomly insert primer-binding sites to facilitate sequencing of large DNA fragments $(>5 \mathrm{~kb})$. The DNA sequence of cloned fragments was determined for both strands with automated dideoxy-sequencing systems (ALF DNA sequencer [GE Healthcare, Little Chalfont, U.K.] and ABI377 DNA sequencer [Applied Biosystems, Foster City, CA, U.S.A.]). Subsequently, the DNA of the sequences was interpreted via computer assistance with Institut Pasteur biological software.

The obtained sequence was annotated by means of online Xbase bacterial genome annotation that uses the Glimmer gene prediction software (Delcher et al. 2007). For identification of protein-coding genes, the genome sequence was translated in six frames to generate potential protein products of open reading frames longer than $90 \mathrm{bp}$, considering ATG and GTG as potential initiation codons when preceded by a putative ribo- 
some-binding site in agreement with the consensus sequence GAPuPuNGAPuTC (Crespi et al. 1994). The potential protein sequences were compared with the nonredundant SwissProt/TrEMBL databases by means of the BLASTP program and an $E$ value of $10^{-6}$ as cut-off (Altschul et al. 1997). When the initiation codons of the potential protein sequences could be identified without ambiguity by manual inspection, they were included in the gene list.

The Alien Hunter application was used to predict the occurrence of regions acquired via HGT (Vernikos and Parkhill 2006; Sanger Institute website).

\section{Scanning electron microscopy.}

Samples were fixed in $4 \%$ formaldehyde and $1 \%$ glutaraldehyde in $0.1 \mathrm{M}$ cacodylate buffer ( $\mathrm{pH} 7.2$ ), post fixed in $2 \%$ $\mathrm{OsO}_{4}$ in $\mathrm{H}_{2} \mathrm{O}$ overnight at $4^{\circ} \mathrm{C}$, dehydrated in an ethanol series, and dried in liquid $\mathrm{CO}_{2}$ with a critical point dryer. The samples were mounted on stubs with double-sticky adhesive, goldcoated with a sputter coater, and viewed with a JSM 840 microscope (Jeol, Tokyo).

\section{Generation of recombinant $\boldsymbol{R}$. fascians strains.}

For the functional analysis of the cutinase, nrp, and stk loci, mutants were isolated via double homologous exchange recombination or disruptive single homologous recombination (Crespi et al. 1994). Therefore, the suicide plasmids pSPIP $\Delta$ cuti, pCRDVprep, pUCIFAnrp5, pBLIFstk1, and pBLIFstk4 were constructed. For the mutation of $p F i \_086$, a 1.9-kb BglII and a 1.7-kb $S m a \mathrm{I}-B g l$ II fragment of the cutinase locus were cloned flanking the Km resistance gene (Taylor and Rose 1988) into pSP72. Then, the $\mathrm{Cm}$ resistance $(\mathrm{cmr})$ gene was introduced as a 2.5-kb XbaI fragment (Desomer et al. 1992), generating the final construct pSPIP $\Delta c u t i$ that carries a 474-bp deletion in $p F i \_086$. For the mutation of $p F i$ 102, a 530-bp internal fragment was amplified via PCR with the primers PREP-FW and PREP-REV (Supplementary Table S3) and cloned into pCRBlunt, generating pCRDVprep. For the generation of the nrp5 mutant, a $5-\mathrm{kb}$ BamHI fragment was cloned into pUC18 and then a $2.3-\mathrm{kb}$ EcoNI fragment was deleted. The final construct pUCIF $\Delta$ nrp5 was obtained after introduction of the $\mathrm{cmr}$ as a $2.5-\mathrm{kb} \mathrm{XbaI}$ fragment. For the stkl gene mutant, a $1.0-\mathrm{kb}$ SalI fragment was cloned into pBluescript. For the mutation of stk4, an 880-kb internal fragment was amplified via PCR with the primers STK4FW and STK4-REV and cloned into pBluescript as an $\mathrm{XbaI-}$ Bam HI fragment. Both stk cloning intermediates were finalized by introduction of the $\mathrm{cmr}$ gene as a $2.5-\mathrm{kb} \mathrm{XbaI}$ fragment, yielding the final constructs pBLIFstkl and pBLIFstk4.

For expression analysis, three additional suicide plasmids (pSPIFnrp5gus, pSPIFstk1gus, and pSPIFstk4gus) were constructed. Fragments of 770 bp (nrp5), 2,405 bp (stk1), and 2,388 bp (stk4) were amplified by PCR (primers NRP5GUSFW/REV, STK1GUSFW/REV, and STK4GUS-FW/REV) and cloned first into pGUS1 as HindIII-PstI (nrp5) or HindIII-SphI (stk1 and stk4) fragments. Subsequently, the gus fusions were isolated from these cloning intermediates as HindIII-XbaI fragments and cloned into pSP72. Finally, the $c m r$ gene was introduced as an $\mathrm{XbaI}$ fragment, yielding the final constructs.

After introduction of these plasmids into strain D188 via electrotransformation (Desomer et al. 1990) and selection on Cm (pBLIFstk1, pBLIFstk4, pSPIFnrp5gus, pSPIFstk1gus, and pSPIFstk4gus) or $\mathrm{Km}$ (pCRDVprep), correct recombinations into the respective loci were verified by DNA gel blot hybridization with gene-specific probes. For the generation of D188$\Delta c u t i$ and D188- $\Delta n r p 5$ via exchange recombination, the first recombination was selected on $\mathrm{Cm}$. For D188- $\Delta$ cuti, the second recombination was screened on $\mathrm{Km}$ accompanied by the loss of $\mathrm{Cm}$ resistance. For D188- $\Delta n r p 5$, the second recombination was evaluated by the loss of the $\mathrm{Cm}$ resistance. Both recombination events were verified by DNA gel blot hybridization.

For the complementation of D188- $\Delta c u t i$, two replicating plasmids were constructed (pRFDVpFi_087 to pRFDVpFi_086 and pRFDVpFi_087 to pRFDVpFi_085), for which a $3.1-\mathrm{kb}$ ApoI fragment and a 3.6-kb ApoI/Pst I fragment, respectively, were first cloned into pBluescript and then retrieved as HindIII/ $X b a I$ fragments to be cloned into the shuttle vector pRF37 to yield the final constructs. The plasmids were introduced into D188- $\Delta$ cuti by selection on Phleo.

\section{Conjugation.}

The conjugation experiments were done with 1:1 culture ratios on nitrocellulose filters (pore size $0.45 \mu \mathrm{m}$, diameter 25 mm; Millipore, Bedford, MA, U.S.A.) as described (Desomer et al. 1988). Serial dilutions of the conjugation mixtures were plated on Sm-containing YEB medium to count the number of acceptors, whereas undiluted samples were plated on $\mathrm{Sm}+\mathrm{Km}$ containing YEB medium to select for transconjugants. The transfer efficiency was expressed as the number of Km-resistant transconjugants divided by the number of recipient cells in the mating mixture.

\section{Expression analysis.}

To evaluate the inducibility of the expression of $n r p 5$, stkl, and $s t k 4$, the gus reporter strains were grown in MinA medium $\left(0.1 \% \mathrm{NH}_{4} \mathrm{SO}_{4}, 0.025 \% \mathrm{MgSO}_{4}\right.$, and $0.001 \%$ thiamine $)$ under inducing and control conditions as described (Temmerman et al. 2000). Expression was monitored with the substrate 4-methylumbelliferyl- $\beta$-D-glucuronide (Temmerman et al. 2000).

\section{Plant infection methods.}

Sterile N. tabacum (L.) W38 seed were germinated on solid Murashige and Skoog (MS) basal mineral medium supplemented with $1 \%$ sucrose. For the leaf inoculation assay, leaves of 3- to 4-week-old plants were excised and placed on MS medium, and a drop of bacterial culture was applied to the leaf surface without prior wounding. Phenotypes were scored 3 weeks after inoculation.

\section{Cloning, heterologous expression, and purification of Stk proteins.}

For the enzymatic analyses of the Stk1, Stk2, Stk3, and Stk4 proteins, plasmids were generated producing N-terminal MBP fusions. Gene fragments of 1.27, 0.99, 1.46, 0.88, and $0.94 \mathrm{~kb}$, without the predicted TMD, were amplified via PCR with the primers STK1SOL-FW/REV, STK1TRUNC-FW/REV, STK2SOL-FW/REV, STK3-FW/REV, and STK4SOLFW/REV, respectively. The PCR fragments were cloned as BamHI-HindIII $\left(s t k 1_{s o l}\right)$, EcoRI-PstI $\left(s t k 2_{\text {sol }}\right)$, or EcoRI-BamHI fragments (stk $1_{\text {trunc }}, s t k 3$, and $s t k 4_{\text {sol }}$ ) into pMALc2X. The resulting plasmids (pMALstk $1_{\text {sol }}$, pMALstk $1_{\text {trunc }}, \mathrm{pMALstk} 2_{\text {sol }}$, pMALstk3, and pMALstk4 $4_{\text {sol }}$ ) were introduced into the $E$. coli DH5 $\alpha$ strain via heat shock transformation and selection on $\mathrm{Cb}$. The MBP fusion proteins were purified from E. coli according to Riggs (2000).

\section{In vitro kinase and phosphatase assays.}

Autophosphorylation reactions were done for $30 \mathrm{~min}$ at room temperature with $5 \mu \mathrm{g}$ of purified MBP-Stk $1_{\text {sol }}$ or Stk $1_{\text {trunc }}$ in the presence of $10 \mu \mathrm{M}\left[\gamma^{-}{ }^{33} \mathrm{P}\right] \mathrm{ATP}$ (EasyTides, NEN Radiochemicals; Perkin-Elmer, Norwalk, CT, U.S.A.) as described (Jin and Pancholi 2006). The kinase buffer was supplemented with $\mathrm{MnCl}_{2}, \mathrm{MgCl}_{2}$, or $\mathrm{CaCl}_{2}$ at varying concentrations (ranging from 0 to $10 \mathrm{mM}$ ). For transphosphorylation, $5 \mu \mathrm{g}$ of purified MBP-Stk3 or MBP-Stk4 $4_{\text {sol }}$ was added to the autophosphorylation reaction. 
The phosphatase activity of MBP-Stk $2_{\text {sol }}(5 \mu \mathrm{g})$ was assayed by hydrolysis of $20 \mathrm{mM}$ pNPP as described (Jin and Pancholi 2006). The enzyme reaction was carried out at different concentrations of $\mathrm{MnCl}_{2}, \mathrm{MgCl}_{2}$, or $\mathrm{CaCl}_{2}$ (ranging from 0 to 10 $\mathrm{mM})$ at room temperature.

To demonstrate the interaction between Stk1 and Stk2, autophosphorylated MBP-Stk $1_{\text {sol }}$ was separated from unincorporated $\left[\gamma_{-}{ }^{33} \mathrm{P}\right] \mathrm{ATP}$ on a Bio-Spin 30 Chromatography Column (Bio-Rad), resuspended in phosphatase buffer, and incubated with $5 \mu \mathrm{g}$ of purified MBP-Stk $2_{\text {sol }}$.

\section{Other molecular techniques.}

Plasmid and genomic DNA isolation, DNA cloning, DNA gel blot and colony hybridization, E. coli heat shock transformation, and other general manipulations were done according to Sambrook and Russell (2001). Primers for cloning or sequencing purposes were designed via the Primer3 program. PCR reactions were done with Phusion DNA Polymerase (Finnzymes, Espoo, Finland).

\section{ACKNOWLEDGMENTS}

We thank J. Gielen and R. Villarroel for help with the sequencing; A. Dolzblasz, S. Fetzner, and S. Kolckenbrock for technical assistance and training; K. Cornelis, E. Stes, and T. Ritsema for the biofilm images; T. Maes, R. Dreesen, and W. Temmerman for cosmid analysis; K. Goethals for fruitful discussions; K. Spruyt for plant photography; and M. De Cock for help in preparing the manuscript. This work was supported by the "Geconcerteerde Onderzoeksacties" (GOA 01GA0105) of the Ghent University. I. Francis and I. Pertry are indebted to the Agency for Innovation by Science and Technology for a predoctoral fellowship. O. M. Vandeputte is a Postdoctoral Researcher of the F.R.S.-F.N.R.S. (Fonds de la Recherche Scientifique, Belgium).

\section{LITERATURE CITED}

Altschul, S. F., Madden, T. L., Schäffer, A. A., Zhang, J., Zhang, Z., Miller, W., and Lipman, D. J. 1997. Gapped BLAST and PSI-BLAST: A new generation of protein database search programs. Nucleic Acids Res. 25:3389-3402.

Arnold, C., and Hodgson, I. J. 1991. Vectorette PCR: A novel approach to genomic walking. PCR Methods Appl. 1:39-42.

Bao, K., and Cohen, S. N. 2003. Recruitment of terminal protein to the ends of Streptomyces linear plasmids and chromosomes by a novel telomerebinding protein essential for linear DNA replication. Genes Dev. 17:774785.

Barash, I., and Manulis-Sasson, S. 2009. Recent evolution of bacterial pathogens: The gall-forming Pantoea agglomerans case. Annu. Rev. Phytopathol. 47:133-152.

Barre, F.-X. 2007. FtsK and SpoIIIE: The tale of the conserved tails. Mol. Microbiol. 66:1051-1055.

Bentley, S. D., Corton, C., Brown, S. E., Barron, A., Clark, L., Doggett, J., Harris, B., Ormond, D., Quail, M. A., May, G., Francis, D., Knudson, D., Parkhill, J., and Ishimaru, C. A. 2008. Genome of the actinomycete plant pathogen Clavibacter michiganensis subsp. sepedonicus suggests recent niche adaptation. J. Bacteriol. 190:2150-2160.

Bignell, D. R. D., Huguet-Tapia, J. C., Joshi, M. V., Pettis, G. S., and Loria, R. 2010. What does it take to be a plant pathogen: Genomic insights from Streptomyces species. Antonie Van Leeuwenhoek 98:179-194.

Carvalho, C. M. L., Aires-Barros, M. R., and Cabral, J. M. S. 1999. Cutinase: From molecular level to bioprocess development. Biotechnol. Bioeng. 66:17-34.

Carver, T. J., Rutherford, K. M., Berriman, M., Rajandream, M.-A., Barrell, B. G., and Parkhill, J. 2005. ACT: The Artemis comparison tool. Bioinformatics 21:3422-3423.

Chen, C. W. 2007. Streptomyces linear plasmids: Replication and telomeres. Pages 33-61 in: Microbial Linear Plasmids, Microbiology Monographs, Vol. 7. F. Meinhardt and R. Klassen, eds. Springer-Verlag, Berlin.

Cornelis, K., Ritsema, T., Nijsse, J., Holsters, M., Goethals, K., and Jaziri, M. 2001. The plant pathogen Rhodococcus fascians colonizes the exterior and interior of the aerial parts of plants. Mol. Plant-Microbe Interact. 14:599-608.

Crespi, M., Messens, E., Caplan, A. B., Van Montagu, M., and Desomer, J. 1992. Fasciation induction by the phytopathogen Rhodococcus fascians depends upon a linear plasmid encoding a cytokinin synthase gene.
EMBO (Eur. Mol. Biol. Organ.) J. 11:795-804.

Crespi, M., Vereecke, D., Temmerman, W., Van Montagu, M., and Desomer, J. 1994. The fas operon of Rhodococcus fascians encodes new genes required for efficient fasciation of host plants. J. Bacteriol. 176:2492-2501.

Danhorn, T., and Fuqua, C. 2007. Biofilm formation by plant-associated bacteria. Annu. Rev. Microbiol. 61:401-422.

Delcher, A. L., Bratke, K. A., Powers, E. C., and Salzberg, S. L. 2007. Identifying bacterial genes and endosymbiont DNA with Glimmer. Bioinformatics 23:673-679.

Depuydt, S., Doležal, K., Van Lijsebettens, M., Moritz, T., Holsters, M., and Vereecke, D. 2008. Modulation of the hormone setting by Rhodococcus fascians results in ectopic KNOX activation in Arabidopsis. Plant Physiol. 146:1267-1281.

Desomer, J., Dhaese, P., and Van Montagu, M. 1988. Conjugative transfer of cadmium resistance plasmids in Rhodococcus fascians strains. J. Bacteriol. 170:2401-2405.

Desomer, J., Dhaese, P., and Van Montagu, M. 1990. Transformation of Rhodococcus fascians by high-voltage electroporation and development of $R$. fascians cloning vectors. Appl. Environ. Microbiol. 56:2818-2825.

Desomer, J., Crespi, M., and Van Montagu, M. 1991. Illegitimate integration of non-replicative vectors in the genome of Rhodococcus fascians upon electrotransformation as an insertional mutagenesis system. Mol. Microbiol. 5:2115-2124.

Desomer, J., Vereecke, D., Crespi, M., and Van Montagu, M. 1992. The plasmid-encoded chloramphenicol resistance protein of Rhodococcus fascians is homologous to the transmembrane tetracycline efflux proteins. Mol. Microbiol. 6:2377-2385.

Finking, R., and Marahiel, M. A. 2004. Biosynthesis of nonribosomal peptides. Annu. Rev. Microbiol. 58:453-488.

Flärdh, K. 2010. Cell polarity and the control of apical growth in Streptomyces. Curr. Opin. Microbiol. 13:758-765.

Francis, I., Gevers, D., Karimi, M., Holsters, M., and Vereecke, D. 2007. Linear plasmids and phytopathogenicity. Pages 99-115 in: Microbial Linear Plasmids, Microbiology Monographs, Vol. 7. F. Meinhardt and R. Klassen, eds. Springer-Verlag, Berlin.

Gal-Mor, O., and Finlay, B. B. 2006. Pathogenicity islands: A molecular toolbox for bacterial virulence. Cell. Microbiol. 8:1707-1719.

Grohmann, E., Muth, G., and Espinosa, M. 2003. Conjugative plasmid transfer in gram-positive bacteria. Microbiol. Mol. Biol. Rev. 67:277-301.

Gröning, J. A. D., Tischler, D., Kaschabek, S. R., and Schlömann, M. 2010. Optimization of a genome-walking method to suit GC-rich template DNA from biotechnological relevant Actinobacteria. J. Basic Microbiol. 50:499-502.

Hanahan, D. 1983. Studies on transformation of Escherichia coli with plasmids. J. Mol. Biol. 166:557-580.

Hayes, C. S., and Low, D. A. 2009. Signals of growth regulation in bacteria. Curr. Opin. Microbiol. 12:667-673.

Jin, H., and Pancholi, V. 2006. Identification and biochemical characterization of a eukaryotic-type serine/threonine kinase and its cognate phosphatase in Streptococcus pyogenes: Their biological functions and substrate identification. J. Mol. Biol. 357:1351-1372.

Jones, G., and Dyson, P. 2006. Evolution of transmembrane protein kinases implicated in coordinating remodeling of gram-positive peptidoglycan: Inside versus outside. J. Bacteriol. 188:7470-7476.

Joshi, M., and Loria, R. 2007. Streptomyces turgidiscabies possesses a functional cytokinin biosynthetic pathway and produces leafy galls. Mol. Plant-Microbe Interact. 20:751-758.

Kalkus, J., Menne, R., Reh, M., and Schlegel, H. G. 1998. The terminal structures of linear plasmids from Rhodococcus opacus. Microbiology 144:1271-1279.

Kato, J.-y., Funa, N., Watanabe, H., Ohnishi, Y., and Horinouchi, S. 2007. Biosynthesis of $\gamma$-butyrolactone autoregulators that switch on secondary metabolism and morphological development in Streptomyces. Proc. Natl. Acad. Sci. U.S.A. 104:2378-2383.

Konz, D., and Marahiel, M. A. 1999. How do peptide synthetases generate structural diversity? Chem. Biol. 6:R39-R48.

Lacey, M. S. 1961. The development of filter-passing organisms in Corynebacterium fascians cultures. Ann. Appl. Biol. 49:634-644.

Larkin, M. J., Kulakov, L. A., and Allen, C. C. R. 2005. Biodegradation and Rhodococcus-masters of catabolic versatility. Curr. Opin. Biotechnol. 16:282-290.

Lawson, E. N., Gantotti, B. V., and Starr, M. P. 1982. A 78-megadalton plasmid occurs in avirulent strains as well as virulent strains of Corynebacterium fascians. Curr. Microbiol. 7:327-332.

LeChevalier, H. A. 1986. Nocardioforms. Pages 1458-1506 in: Bergey's Manual of Systematic Bacteriology, Vol. 2. P. H. A. Sneath, N. S. Mair, M. E. Sharpe, and J. G. Holt, eds. Williams \& Wilkins, Baltimore.

Letek, M., Fiuza, M., Ordóñez, E., Villadangos, A. F., Ramos, A., Mateos, L. M., and Gil, J. A. 2008. Cell growth and cell division in the rod- 
shaped actinomycete Corynebacterium glutamicum. Antonie Van Leeuwenhoek 94:99-109.

Letek, M., González, P., MacArthur, I., Rodríguez, H., Freeman, T. C., Valero-Rello, A., Blanco, M., Buckley, T., Cherevach, I., Fahey, R., Hapeshi, A., Holdstock, J., Leadon, D., Navas, J., Ocampo, A., Quail, M. A., Sanders, M., Scortti, M. M., Prescott, J. F., Fogarty, U., Meijer, W. G., Parkhill, J., Bentley, S. D., and Vázquez-Boland, J. A. 2010. The genome of a pathogenic Rhodococcus: Cooptive virulence underpinned by key gene acquisitions. PLoS Genet. 6:e1001145.

Liang, X., and Van Doren, S. R. 2008. Mechanistic insights into phosphoprotein-binding FHA domains. Accounts Chem. Res. 41:991-999.

Maes, T., Vereecke, D., Ritsema, T., Cornelis, K., Ngo Thi Thu, H., Van Montagu, M., Holsters, M., and Goethals, K. 2001. The att locus of Rhodococcus fascians strain D188 is essential for full virulence on tobacco through the production of an autoregulatory compound. Mol. Microbiol. 42:13-28.

McLeod, M. P., Warren, R. L., Hsiao, W. W. L., Araki, N., Myhre, M., Fernandes, C., Miyazawa, D., Wong, W., Lillquist, A. L., Wang, D., Dosanjh, M., Hara, H., Petrescu, A., Morin, R. D., Yang, G., Stott, J. M., Schein, J. E., Shin, H., Smailus, D., Siddiqui, A. S., Marra, M. A., Jones, S. J. M., Holt, R., Brinkman, F. S. L., Miyauchi, K., Fukuda, M., Davies, J. E., Mohn, W. W., and Eltis, L. D. 2006. The complete genome of Rhodococcus sp. RHA1 provides insight into a catabolic powerhouse. Proc. Natl. Acad. Sci. U.S.A. 103:15582-15587.

Meinhardt, F., and Klassen, R., eds. 2007. Microbial Linear Plasmids, Microbiology Monographs, Vol. 7. Springer-Verlag, Berlin.

Molle, V., and Kremer, L. 2010. Division and cell envelope regulation by Ser/Thr phosphorylation: Mycobacterium shows the way. Mol. Microbiol. 75:1064-1077.

Mortier-Barrière, I., Velten, M., Dupaigne, P., Mirouze, N., Piétrement, O., McGovern, S., Fichant, G., Martin, B., Noirot, P., Le Cam, E., Polard, P., and Claverys, J.-P. 2007. A key presynaptic role in transformation for a widespread bacterial protein: DprA conveys incoming ssDNA to RecA. Cell 130:824-836.

Ochman, H., Gerber, A. S., and Hartl, D. L. 1988. Genetic applications of an inverse polymerase chain reaction. Genetics 120:621-623.

Parschat, K., Overhage, J., Strittmatter, A. W., Henne, A., Gottschalk, G., and Fetzner, S. 2007. Complete nucleotide sequence of the 113-kilobase linear catabolic plasmid pAL1 of Arthrobacter nitroguajacolicus Rü61a and transcriptional analysis of genes involved in quinaldine degradation. J. Bacteriol. 189:3855-3867.

Pertry, I. 2009. How the fas locus contributes to $R$. fascians cytokinin production: An in-depth molecular and biochemical analysis. Ph.D. thesis, Ghent University, Belgium.

Pertry, I., Václavíková, K., Depuydt, S., Galuszka, P., Spíchal, L., Temmerman, W., Stes, E., Schmülling, T., Kakimoto, T., Van Montagu, M., Strnad, M., Holsters, M., Tarkowski, P., and Vereecke, D. 2009. Identification of Rhodococcus fascians cytokinins and their modus operandi to reshape the plant. Proc. Natl. Acad. Sci. U.S.A. 106:929-934.

Pertry, I., Václavíková, K., Gemrotová, M., Spíchal, L., Galuszka, P., Depuydt, S., Temmerman, W., Stes, E., De Keyser, A., Riefler, M., Biondi, S., Novák, O., Schmülling, T., Strnad, M., Tarkowski, P., Holsters, M., and Vereecke, D. 2010. Rhodococcus fascians impacts plant development through the dynamic Fas-mediated production of a cytokinin mix. Mol. Plant-Microbe Interact. 23:1164-1174.

Pisabarro, A., Correia, A., and Martín, J. F. 1998. Pulsed-field gel electrophoresis analysis of the genome of Rhodococcus fascians: Genome size and linear and circular replicon composition in virulent and avirulent strains. Curr. Microbiol. 36:302-308.

Rajaonson, S., Vandeputte, O. M., Vereecke, D., Kiendrebeogo, M. Ralambofetra, E., Stévigny, C., Duez, P., Rabemanantsoa, C., Mol, A., Diallo, B., Baucher, M., and El Jaziri, M. 2011. Virulence quenching with a prenylated isoflavanone renders the Malagasy legume Dalbergia pervillei resistant to Rhodococcus fascians. Environ. Microbiol. 13:12361252.

Riggs, P. 2000. Expression and purification of recombinant proteins by fusion to maltose-binding protein. Mol. Biotechnol. 15:51-62.

Sambrook, J., and Russell, D. W., eds. 2001. Molecular Cloning, a Laboratory Manual, 3rd ed. Cold Spring Harbor Laboratory Press, Cold Spring Harbor, NY, U.S.A.

SantaLucia, J., Jr. 1998. A unified view of polymer, dumbbell, and oligonucleotide DNA nearest-neighbor thermodynamics. Proc. Natl. Acad. Sci. U.S.A. 95:1460-1465.

Sauvage, E., Kerff, F., Terrak, M., Ayala, J. A., and Charlier, P. 2008. The penicillin-binding proteins: Structure and role in peptidoglycan biosynthesis. FEMS (Fed. Eur. Microbiol. Soc.) Microbiol. Rev. 32:234-258.

Schäfer, W. 1993. The role of cutinase in fungal pathogenicity. Trends Microbiol. 1:69-71.

Sekine, M., Tanikawa, S., Omata, S., Saito, M., Fujisawa, T., Tsukatani,
N., Tajima, T., Sekigawa, T., Kosugi, H., Matsuo, Y., Nishiko, R., Imamura, K., Ito, M., Narita, H., Tago, S., Fujita, N., and Harayama, S. 2006. Sequence analysis of three plasmids harboured in Rhodococcus erythropolis strain PR4. Environ. Microbiol. 8:334-346.

Simón-Mateo, C., Depuydt, S., de Oliveira Manes, C. L., Cnudde, F., Holsters, M., Goethals, K., and Vereecke, D. 2006. The phytopathogen Rhodococcus fascians breaks apical dominance and activates axillary meristems by inducing plant genes involved in hormone metabolism. Mol. Plant Pathol. 7:103-112.

Stange, R. R., Jeffares, D., Young, C., Scott, D. B., Eason, J. R., and Jameson, P. E. 1996. PCR amplification of the fas-1 gene for detection of virulent strains of Rhodococcus fascians. Plant Pathol. 45:407-417.

Stecker, C., Johann, A., Herzberg, C., Averhoff, B., and Gottschalk, G. 2003. Complete nucleotide sequence and genetic organization of the 210-kilobase linear plasmid of Rhodococcus erythropolis BD2. J. Bacteriol. 185:5269-5274.

Stes, E., Vandeputte, O., El Jaziri, M., Holsters, M., and Vereecke, D. 2011. A successful bacterial coup d'état: How Rhodococcus fascians redirects plant development. Annu. Rev. Phytopathol. 49:69-86.

Surtees, J. A., and Funnell, B. E. 2003. Plasmid and chromosome traffic control: How ParA and ParB drive partition. Curr. Topics Dev. Biol. 56:145-180.

Taylor, L. A., and Rose, R. E. 1988. A correction in the nucleotide sequence of the Tn903 kanamycin resistance determinant in pUC4K. Nucleic Acids Res. 16:358.

Temmerman, W., Vereecke, D., Dreesen, R., Van Montagu, M., Holsters, M., and Goethals, K. 2000. Leafy gall formation is controlled by fas $R$, an AraC-type regulatory gene in Rhodococcus fascians. J. Bacteriol. 182:5832-5840.

Tomich, M., Planet, P. J., and Figurski, D. H. 2007. The tad locus: Postcards from the widespread colonization island. Nat. Rev. Microbiol. 5:363-375.

Vandeputte, O., Öden, S., Mol, A., Vereecke, D., Goethals, K., El Jaziri, M., and Prinsen, E. 2005. Biosynthesis of auxin by the gram-positive phytopathogen Rhodococcus fascians is controlled by compounds specific to infected plant tissues. Appl. Environ. Microbiol. 71:1169-1177.

van der Geize, R., and Dijkhuizen, L. 2004. Harnessing the catabolic diversity of rhodococci for environmental and biotechnological applications. Curr. Opin. Microbiol. 7:255-261.

Van Melderen, L., and Saavedra De Bast, M. 2009. Bacterial toxin-antitoxin systems: More than selfish entities? PLoS Genet. 5:e1000437.

Vereecke, D., Burssens, S., Simón-Mateo, C., Inzé, D., Van Montagu, M., Goethals, K., and Jaziri, M. 2000. The Rhodococcus fascians-plant interaction: Morphological traits and biotechnological applications. Planta 210:241-251.

Vereecke, D., Cornelis, K., Temmerman, W., Jaziri, M., Van Montagu, M., Holsters, M., and Goethals, K. 2002. Chromosomal locus that affects the pathogenicity of Rhodococcus fascians. J. Bacteriol. 184:1112-1120.

Vernikos, G. S., and Parkhill, J. 2006. Interpolated variable order motifs for identification of horizontally acquired DNA: Revisiting the Salmonella pathogenicity islands. Bioinformatics 22:2196-2203.

Vivian, A., Murillo, J., and Jackson, R. W. 2001. The roles of plasmids in phytopathogenic bacteria: Mobile arsenals? Microbiology 147:763-780.

West, N. P., Chow, F. M. E., Randall, E. J., Wu, J., Chen, J., Ribeiro, J. M C., and Britton, W. J. 2009. Cutinase-like protein of Mycobacterium tuberculosis: Characterization of their variable enzymatic functions and active site identification. FASEB (Fed. Am. Soc. Exp. Biol.) J. 23:16941704

Wu, L. J., and Errington, J. 2003. RacA and the Soj-Spo0J system combine to effect polar chromosome segregation in sporulating Bacillus subtilis. Mol. Microbiol. 49:1463-1475.

Yeats, C., Finn, R. D., and Bateman, A. 2002. The PASTA domain: A $\beta$ lactam-binding domain. Trends Biochem. Sci. 27:438-440.

Zhang, W., and Shi, L. 2004. Evolution of the PPM-family protein phosphatases in Streptomyces: Duplication of catalytic domain and lateral recruitment of additional sensory domains. Microbiology 150:4189-4197.

Zhu, L., Zhang, Y., Teh, J.-S., Zhang, J., Connell, N., Rubin, H., and Inouye, M. 2006. Characterization of mRNA interferases from Mycobacterium tuberculosis. J. Biol. Chem. 281:18638-18643.

\section{AUTHOR-RECOMMENDED INTERNET RESOURCES}

Wellcome Trust Sanger Institute website: www.sanger.ac.uk Institut Pasteur biological software: bioweb2.pasteur.fr/intro-en.html National Institute of Technology and Evaluation website: www.bio.nite.go.jp/dogan/project/view/OPACUS

Sanger Institute Alien Hunter software: www.sanger.ac.uk/resources/software/alien_hunter 